\title{
TŘI ARTEFAKTY ÚŠTĚCKÉHO HRADU A PROBLÉMY JEJICH INTERPRETACE
}

\section{FRANTIŠEK GABRIEL}

Abstrakt: Hodnoceni tři nemovitých artefaktů, získaných archeologickým výzkumem na hradě v Úštěku. Cílem je jejich datování a určení možné funkce.

Klíčová slova: topeniště - zdivo-objekt-datace-funkce.

\section{Three artefacts from Úštěk Castle and the problems with their interpretation}

Abstract: The paper assesses three immovable artefacts yielded by archaeological research into Úštěk Castle. The main objective was their dating and the determination of their possible function.

Key words: hearth-masonry-feature-dating-function.

V roce 2012 provádělo regionální muzeum v Teplicích předstihový archeologický výzkum na městském hradě v Úštěku. Výzkum řešil plnou plochu nových inženýrských sítí, plánovaných mimo současnou zástavbu hradního jádra. Plánovaná plocha byla rozdělena na dvě sondy. Sonda 1b/12 ležela v ose nádvoří a na východní straně pokračovala zalomením v pravém úhlu k severu jako sonda 1a/12. Po svém zalomení prot’ala např́íč východní polovinu odstraněného severního křídla až k průchodu severní obvodovou zdí. Sonda 2/12 navázala na předchozí výkop na dvoře sousední fary a pokračovala východním směrem (Gabriel 2014; obr. 1).

Sonda 1a/12 odkryla objekt otopného zařízení severního křídla. Sonda 1b/12 doplnila kontext otopného zařízení a informace o základech zdi, odkryté v sondě 2/82 (Gabriel 1983;

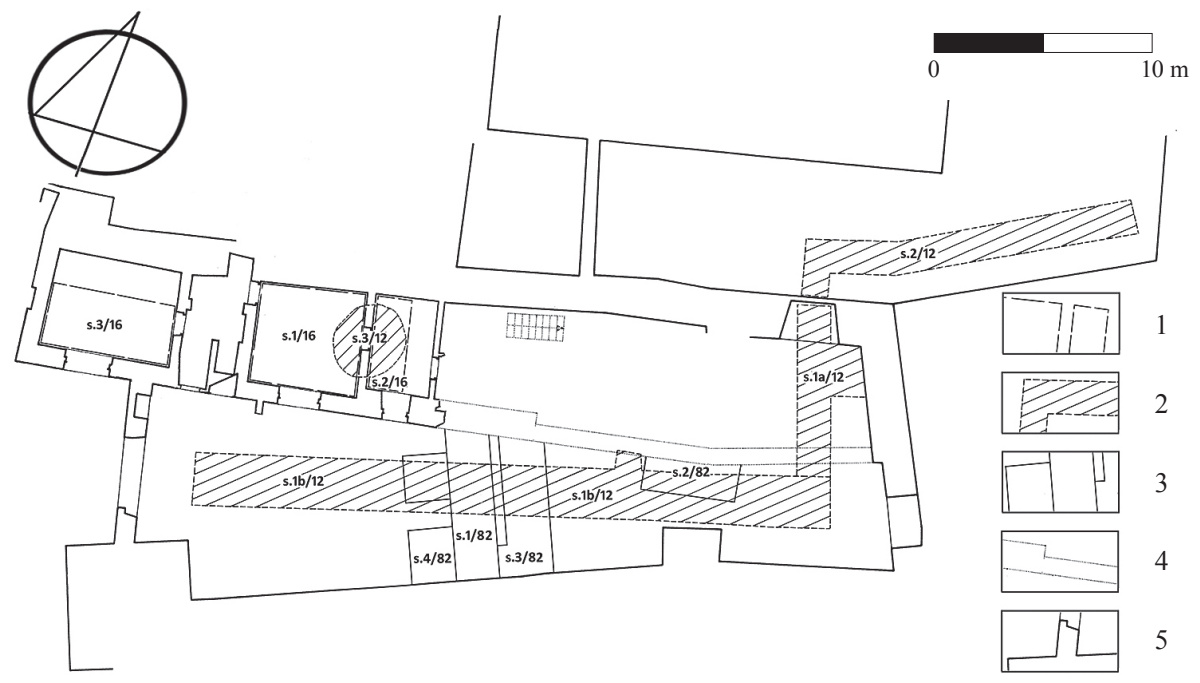

Obr. 1. Rozvržení sond na hradě v Úštěku (za lomítkem rok výzkumu). 1 - sondy z roku 2016; 2 - sondy z roku 2012; 3 - sondy z roku 1983; 4 - zbourané zdivo; 5 - stojící zdivo. Úprava kresby z Tématická mapa od AGM, Ing. J. Chmelír, 2012.

Abb. 1. Verteilung der Sondierschnitte auf der Burg in Úštěk (hinter dem Schrägstrich das Grabungsjahr). 1 - Sondierschnitte aus dem Jahr 2016; 2 - aus dem Jahr 2012; 3 - Sondierschnitte aus dem Jahr 1983; 4 - abgerissenes Mauerwerk; 5 - stehendes Mauerwerk. Bearbeitung der Zeichnung anhand der Thematischen Karte von AGM, Ing. J. Chmelír 2012. 
Gabriel-Smetana 1986). Při dnes odstraněné jižní obvodové zdi severního křídla hradu zasáhla čtvercový objekt, který po rozšíření odkryla.

Cílem článku je pouze dílčí hodnocení tří výzkumem odkrytých artefaktů, jejich kontextů a s nimi spojených interpretačních problémů. Není jím předložení modelu vývoje hradu, ani interpretace všech informací získaných archeologickým výzkumem. Tento úkol vyžaduje i studium nadzemních staveb, což ovšem přesahuje možný rozsah článku. Informace o nadzemní stavbě je ostatně nezbytná i při interpretaci odkrytých artefaktů v této práci. Omezuje se však pouze na vyhodnocení základních informací o východní polovině severního křídla hradu, u kterého byly tři studované artefakty odkryty.

\section{Deskripce východní poloviny severního křídla hradního jádra}

Ze severního křídla hradního jádra se dochovala pouze západní polovina, zatímco z východní části, důležité pro předkládanou práci, dnes známe pouze východní a severní obvodovou zed' plnící současně funkci obvodové zdi hradu. Naštěstí před jeho zbouráním, které proběhlo někdy v 80. letech minulého století, provedlo v roce 1970 kvalitní stavební zaměření tehdejšího stavu SÚRPMO Praha (SÚRPMO 1970) a v roce 1982 jeho jižní průčelí zachytila na několika záběrech fotodokumentace archeologického výzkumu Krajského muzea v Teplicích. Pomocí těchto plánů, fotografií, dochovaných reliktů a informací z archeologické sondy 2/82 vznikl popis stavby před zbouráním. Písemné prameny o stavbě, jejím rozsahu, patrování a bourání nehovoří.

\subsection{Průčelí}

Průčelí jsou jedinými dochovanými nebo alespoň několika nekvalitními fotografiemi zdokumentovanými zdmi následně zbořené východní částí severního křídla hradního jádra úštěckého hradu.

\subsubsection{Východní, pravé boční pri̊čeli}

Východní průčelí tvoří zed' přizpůsobující se svojí korunou zástavbě dnes zbořené části křídla. Z výškové hladiny severní zdi (4,83 m) klesá jako štít pultové střechy přízemní části křídla na hladinu 3,25 m koruny zdi východní. Korunu chrání pískovcové desky s pultovým sklonem. Severovýchodní nároží armují pečlivě vysekané pískovcové kvádry, které místy vystupují pod stékavou omítkou. Nároží zdobila nad korunou zdobná pískovcová koule, z níž se zachoval pouze sokl. Převážnou část průčelí překrývá sousední hospodářská přístavba fary.

\subsubsection{Severní, zadni průčelí}

Na severním průčelí se nerovnostmi a různými opadávajícími omítkami odráží řada přestaveb a drobných oprav. V místech, kde se pohledově uplatňuje režné zdivo, převažuje užití pískovcového kamene. Pelasgická struktura pískovcového zdiva na maltu je ve spodních partiích drobnější, ve vyšších partiích jej tvoří pískovcové kvádry. Jiná staviva (cihla, alkalický bazalt), užitá jako šíbry, posloužila později také pro vyzdívky narušených částí zdi. Užití cihel je patrné především v horní partii. Korunu chrání pískovcové desky s pultovým sklonem.

Průčelí dnes prolomily dva okenní otvory, jeden do krovu poblíž západní poloviny křídla a druhý do přízemí při levém nároží. Otvor do krovu je horizontálně obdélný s prostým okosením. Cihlový parapet náleží mladší úpravě.

Otvor v přízemí byl pravděpodobně čtvercový, po prosekání parapetu včetně římsy užívaný jako otvor dveřní mezi parcelou fary a jádrem hradu (obr. 2). Pískovcové veřeje mají značně narušenou snad karlštejnskou profilaci vybíhající ze šikmých ploch soklů. Šikmina, ukloněná k líci, se pravoúhle zalamuje přibližně v polovině veřejí. Překlad karlštejnského profilu neodpovídá světlé šiřce otvoru, takže byl při okrajích upraven nekvalitním hrubým přisekáním. Tato úprava naznačuje druhotné 


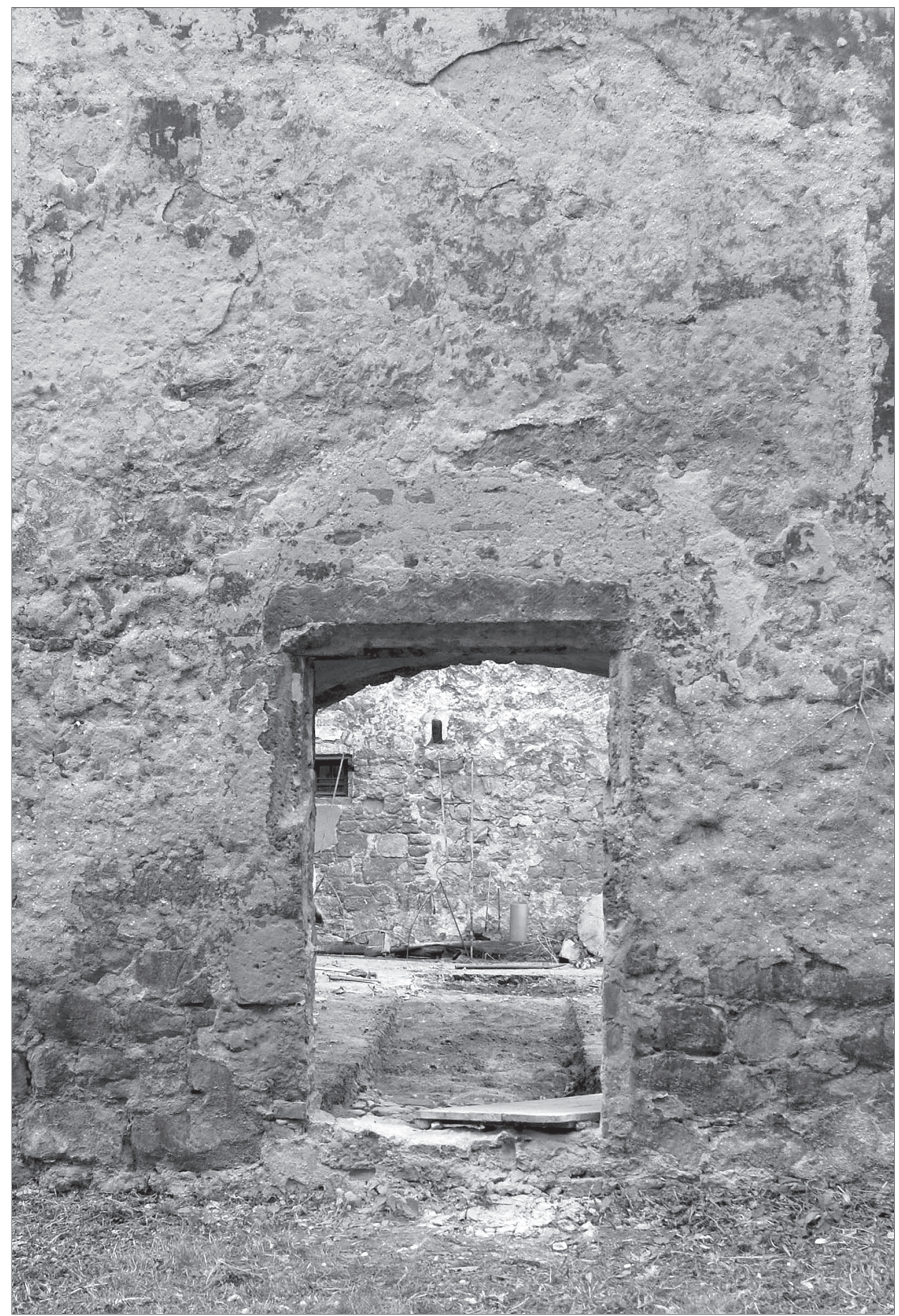

Obr. 2. Okenní otvor karlštejnského profilu upravený na dveřní otvor na severním průčelí severního křídla hradního jádra. Foto L. Kursová.

Abb. 2. Zu einer Türöffnung an der Nordfassade des Nordflügels des Burgkerns umgestaltete Fensteröffnung mit karlstein'scher Profilierung. Foto L. Kursová. 
uplatnění v novém okenním otvoru. Ve špaletách veřejí i překladu dokládají pravidelně vyhloubené kapsy zajištění okna mřiží. Zateklá malta v některých z nich náleží zazdění okna po vyjmutí mříže.

\subsubsection{Západní levé boční průčelí}

Západní průčelí v celém rozsahu kryla západní patrová polovina severního křídla hradu.

\subsubsection{Jižní, hlavni průčeli}

Jižní průčelí lze hodnotit pouze z plánu SÚRPMO (1970, č. 14) a ze starších fotografií. Podle nich prostupovalo dnes zbouraným východním úsekem sedm otvorů, z nichž první, třetí, pátý a sedmý zleva reprezentují okenní otvory a druhý, čtvrtý a šestý otvory dveřní (obr. 3, 4). Z nepravidelně

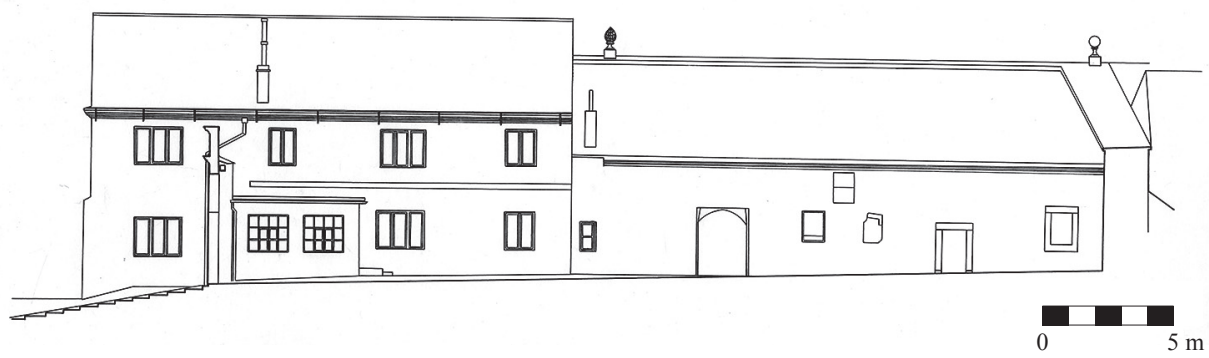

Obr. 3. Jižní průčelí severního křídla hradního jádra. Podle plánu SÚRPMO 1970, obr. 14, překreslila B. Linhartová.

Abb. 3. Südfassade des Nordflügels des Burgkerns. Gemäß Planskizze SÚRPMO 1970, Abb. 14, nachgezeichnet von B. Linhartová.

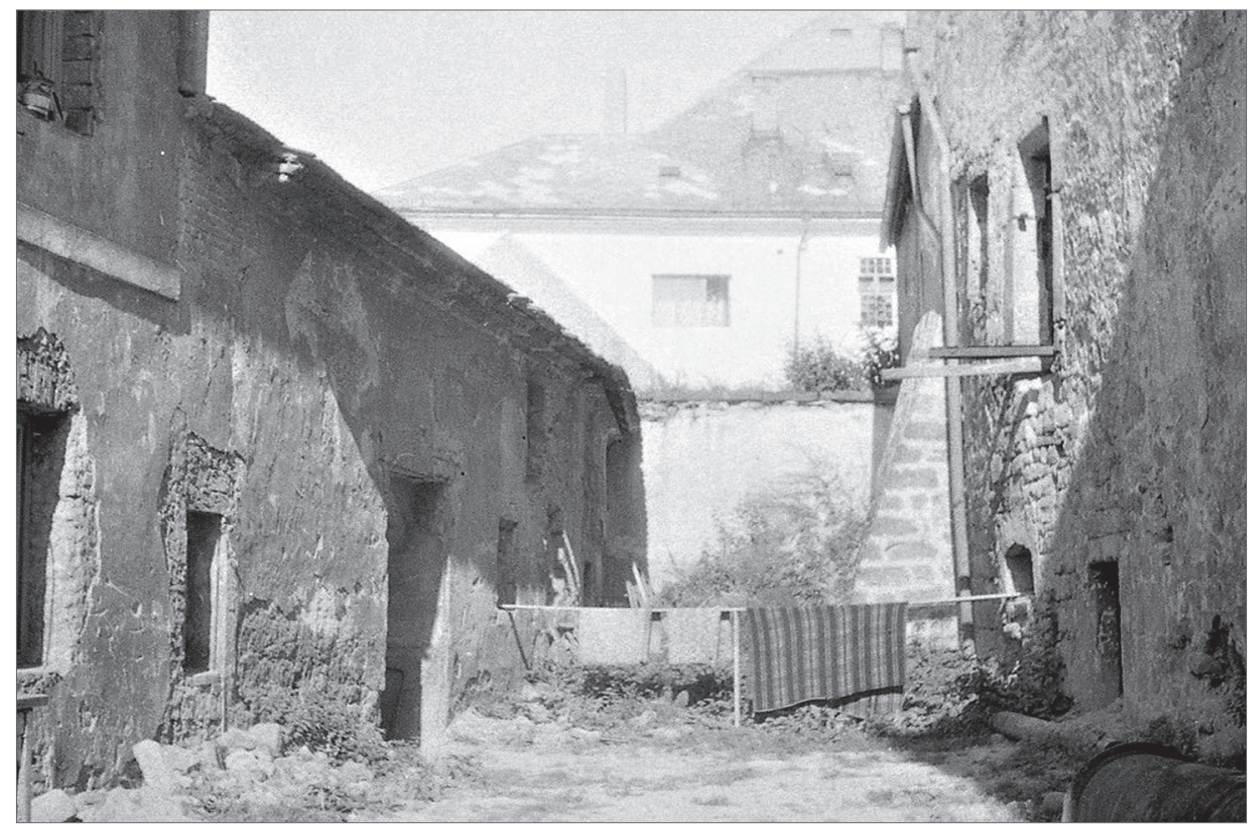

Obr. 4. Východní strana nádvoří s jižním průčelím severního křídla hradního jádra. Foto F. Gabriel.

Abb. 4. Ostseite des Hofes mit Südfassade des Nordflügels des Burgkerns. Foto F. Gabriel. 
rozvržených otvorů různých rozměrů a výšek se v torzálním stavu dochoval pouze první okenní otvor. O okně ve třetí ose dokumentace mnoho informací nenabízí. Z fotodokumentace víme, že otvor v páté ose byl, jak ostatně naznačuje i plán (SÚRPMO 1970, č. 14), zazděn. Poslední z oken známe pouze z plánu, kde jsou po jeho obvodě vykresleny nejspíše prosté neprofilované články. Stejně plán zaznamenal i obvod levého sousedního otvoru dveří, jehož část ukazuje fotodokumentace archeologického výzkumu. Mezi ním a zazděným okenním otvorem se průčelí půdorysně zalamovalo. Zalomení koresponduje s východním lícem základu zdi odkrytého v sondě 2/82. Opad omítek ukázal rozdělení zdi spárou na západní a východní část. Spáru přerušilo zašmorcování východní zdi do zdi západní (obr. 5). Pod korunou okapní římsy se v ose přízemní části otvíraly do krovu dveře, přístupné po žebříku. Široký a vysoký dveřní otvor druhé osy náležel vratům, dovolujícím vjezd do interiéru menším povozem.

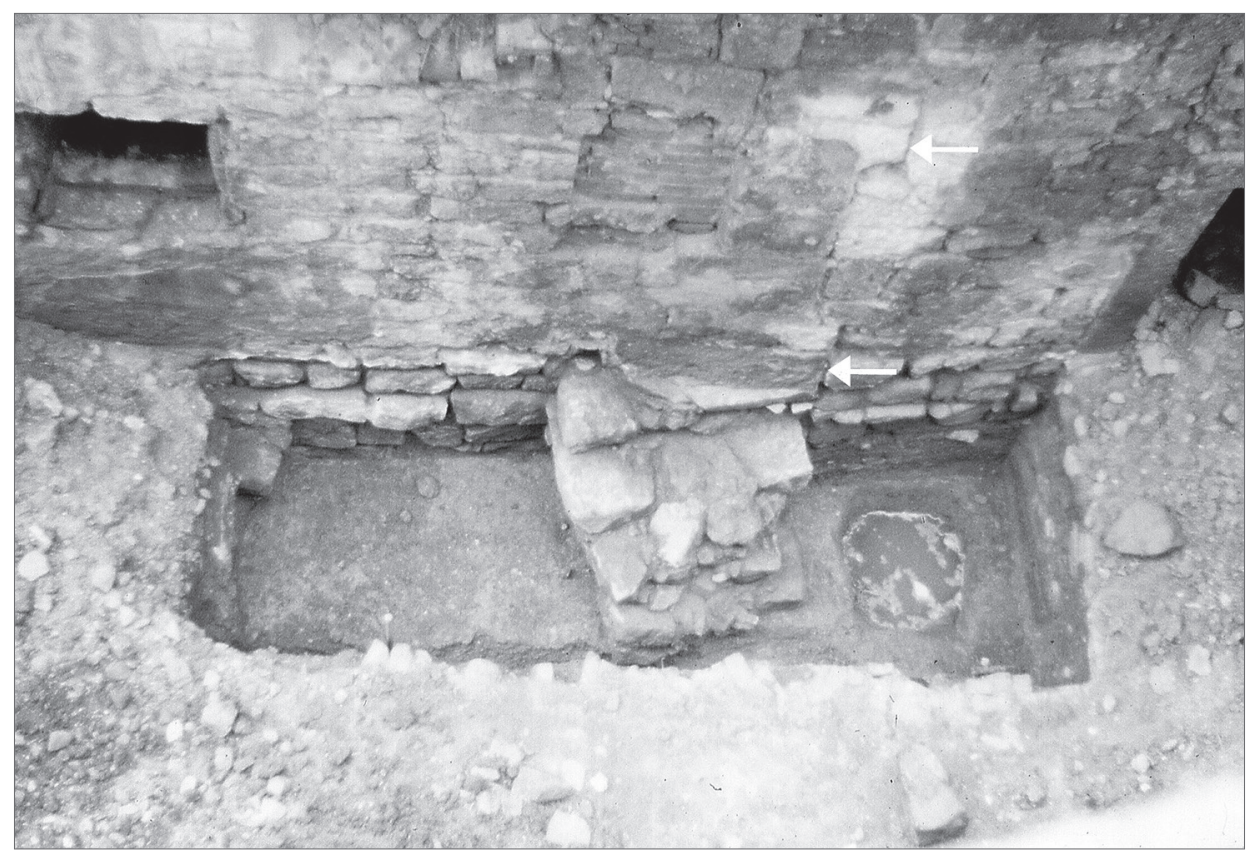

Obr. 5. Jižní obvodová zed’ severního křídla hradu nad sondou 2/82. Nad pravým lícem vystupujícího základu zdi je patrná spára (viz šipky) se šmorcem zprava. Foto F. Gabriel.

Abb. 5. Südliche Außenmauer des Nordflügels der Burg oberhalb von Sondierschnitt 2/82. Über der rechten Flucht des hervortretenden Fundaments ist die Fuge (siehe Pfeile) mit dem Schmarz von rechts erkennbar. Foto F. Gabriel.

\subsection{Dispozice východní poloviny severního kř́dla}

Rozvrh dispozice a její formu známe pouze z plánové dokumentace (SÚRPMO 1970, č. 3, 4, 9).

\subsubsection{Dispozice př́zemí}

Interiér přízemí dělily dvě příčky do tří dílů (obr. 6). Západní z nich, soudě podle plánu (SÚRPMO 1970, č. 3), rozdělily slabé cihlové př́ičky (méně než 0,20 m) do čtyř místností a vydělily tak dvě za sebou položené plochostropé prostory vlevo a dvě za sebou položené prostory vpravo, zastropené plnou až mírně stlačenou příčně orientovanou valenou klenbou. Rovněž střední díl vydělovala od 


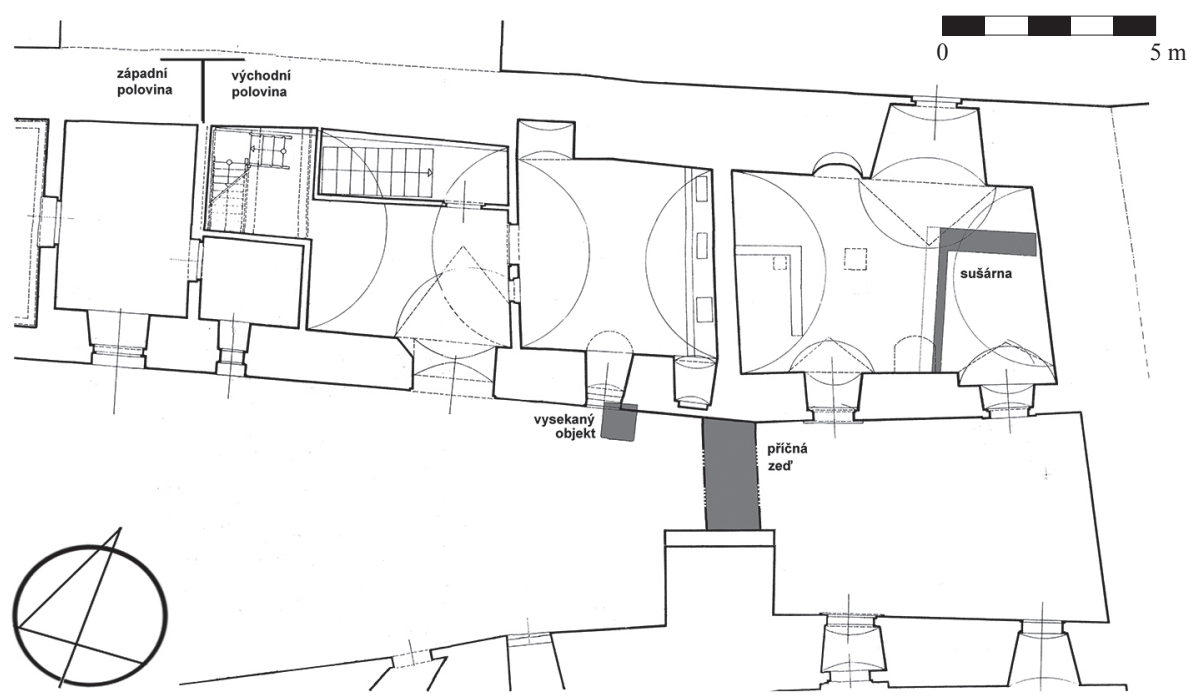

Obr. 6. Dispozice přízemí východní poloviny severního kř́ída hradu s vyznačenými artefakty. Podle plánu SÚRPMO 1970, obr. 2, překreslila B. Linhartová.

Abb. 6. Disposition des Erdgeschosses der östlichen Hälfte des Nordflügels der Burg mit eingezeichneten Artefakten. Gemäß Planskizze SURPMO 1970, Abb. 2, nachgezeichnet von B. Linhartová.

západního slabší cihlová prř́čka (méně než $0,25 \mathrm{~m}$ ). Nad dílem, přístupným zleva, pokračovala klenba z východního dílu. Je téměř jisté, že cihlové příčky dělily jednu místnost, kterou v její ose zpř́istupňovala vrata, dovolující průjezd i menšímu povozu.

Větší význam měla přičcka vydělující západní díl. Svojí tloušt'kou 0,60 m přesahovala ostatní příčky. Tato tloušt'ka však mohla být původně ještě větší, přičteme-li $0,70 \mathrm{~m}$ tlustý sokl koryt. Dosáhla by tak 1,30 m tloušt'ky západní části obvodové zdi a základu odkrytého sondou 2/82, na jehož líc navazuje jak polohou, tak i směrem.

Třetí díl zleva sklenula rovněž mírně stlačená valená klenba příčné orientace. Jak je dosud dobře patrné na dochovaných reliktech sklenutí, dosedají patky klenby na plentu severní i jižní obvodové zdi křídla a plenta zvětšila i tloušt'ku obvodové východní zdi. Přiložení plenty naznačuje i líc, který má v místě zřícení plenty strukturu pelasgického zdiva pouze s ojedinělým užitím čediče a pískovcovými hrubě přisekanými kvádry, zbarvenými do červena propálením. Plenta zbarvená do červena není, obsahuje však vedle pískovcových hrubě přisekaných kvádrů i četné šíbry z alkalického bazaltu a cihel.

Severní stěnou ji prosvětloval okenní otvor s vybouraným parapetem. Výklenek okna sklenul segment, pravděpodobně však vložený pod plný oblouk při některé z úprav. Vyloučit nelze ani vybavení výklenku lavicemi, při úpravách odstraněnými. Jižní, nedochovanou stěnou se vlevo otevíral dveřní otvor a vpravo otvor okenní, který zřejmě prostupoval zdí bez plenty. Všechny výklenky otvorů do místnosti prostupovaly lunetami trojbokých výsečí klenby. Mezi předními výsečemi vykreslil plán čtyřbokou výseč se segmentovou lunetou.

\subsubsection{Krov východní poloviny severního křidla}

Krov prosté pultové konstrukce naznačoval jakési provizorní řešení, které mohlo nahradit odstranění prvního patra, dokládaného dosud patrným okenním otvorem se sedátky ve výklenku. Možnou reminiscencí na patro mohou být i otvory vyzděné z cihel ve výrazném stavebním zásahu zadní obvodové zdi (obr. 7). 


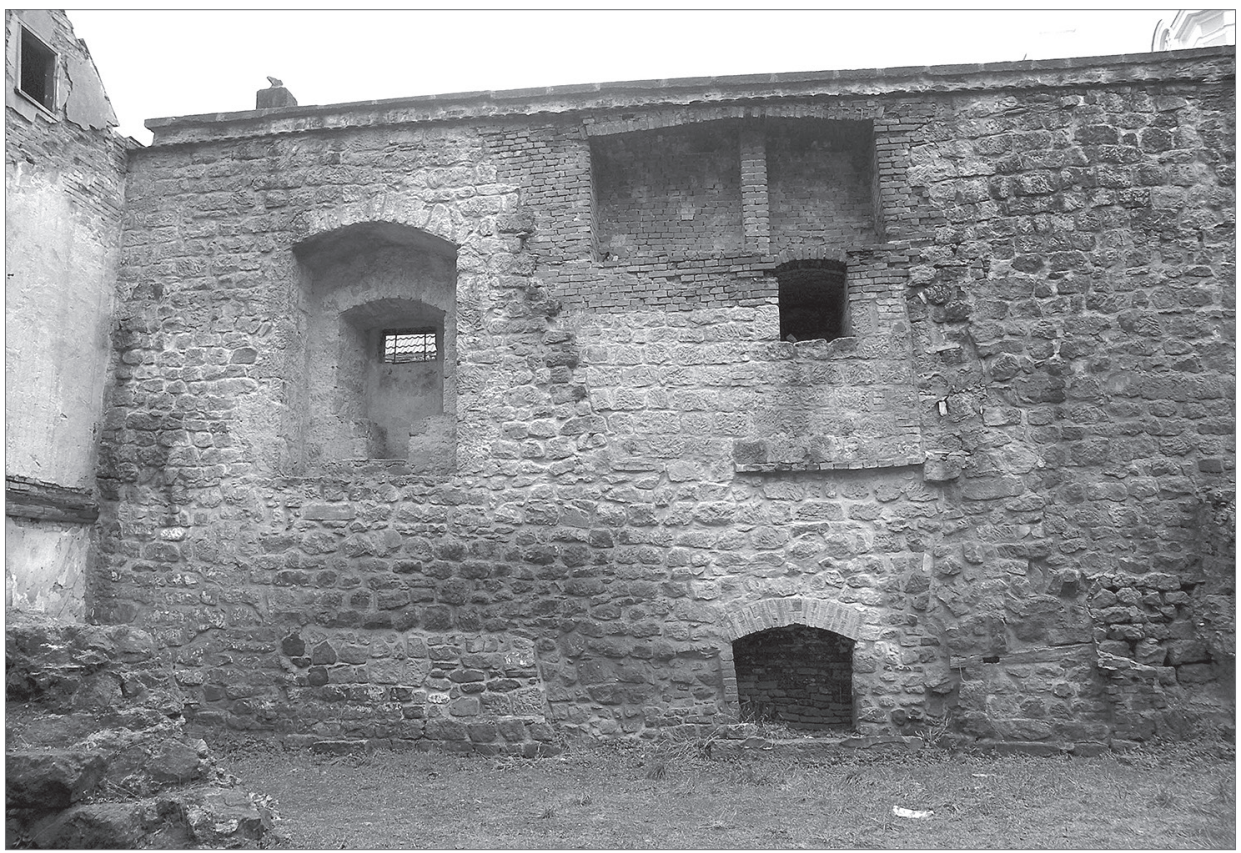

Obr. 7. Severní obvodová zed’ severního křídla hradního jádra po zbourání stavby. Foto L. Kursová.

Abb. 7. Nördliche Außenmauer des Nordflügels des Burgkerns nach Abriss des Gebäudes. Foto L. Kursová.

\section{Výsledky archeologického výzkumu}

Archeologické výzkumy, které proběhly v jádře úštěckého hradu, přinesly řadu cenných informací o vývoji staveb a datování stavebních etap, fází a mikrofází. Tato práce prezentuje tři sondy dotýkající se východní poloviny severního křídla hradu.

\subsection{Sondy 2/82 a 1b/12 se základy př́ičné zdi}

Sonda 2/82 přisedala k jižní obvodové zdi severního křídla hradního jádra v místech mírného zalomení, ve kterém se stýkají dvě různě tlusté zdi. Zatímco západní zed' měla tloušt'ku $1,30 \mathrm{~m}$, východní zed', přiložená, jak již víme ze stratigrafie jižního průčelí, později, měla tloušt'ku pouze $1,15 \mathrm{~m}$. Se základem západní zdi je u zlomu provázán základ rovněž $1,30 \mathrm{~m}$ tlusté prř́čné zdi vybíhající pod tupým úhlem k jihu (obr. 5). Její východní líc svírá s východní zdí pravý úhel. Základ přerušil v sondě výkop inženýrské sítě, její relikt však pokračoval v sondě $1 \mathrm{~b} / 12$. I přes její narušení dalším výkopem zachytily výzkumy délku zdi v délce ca $2,50 \mathrm{~m}$. Je tedy zřejmé, že zed', prot’atá v minulosti dvěma výkopy inženýrských sítí, směřovala k severovýchodnímu nároží dvoupatrové stavby jižního křídla, dnes zakrytému opěrákem. Nepochybné je její provázání se západním úsekem jižní obvodové zdi severního kř́íla, se kterou má odkrytý základ asi stejnou hloubku založení. Obě prostupují povrch do jílovitohlinité vrstvy, která tvořila podloží antropogenního souvrství. Základ východní zdi odkrytý sondou $2 / 82$ je výrazně mělčí.

\subsection{Sonda 1a/12 s otopným zař́izením}

Druhá sonda, které se předkládaná práce věnuje, odkryla pod podlahou východní místnosti severního křídla hradu část artefaktu, který, po rozšíření sondy východním směrem až k obvodové zdi, 
interpretujeme jako podzemní část otopného zařízení v podobě hlavního a bočního teplovzdušného kanálu (obr. 8, 9). Z hlavního topného kanálu severojižního směru zachytil výzkum pouze východní polovinu. Vycházel od přikládacího otvoru, který prostupoval jižní obvodovou zdí a směřoval k severu, kde končil 1,30 m preded okenním výklenkem prostupujícím zadní zdí. V jeho závěru odbočovalo $\mathrm{v}$ šiřce $0,52 \mathrm{~m}$ až $\mathrm{k}$ vnitřnímu líci východní zdi domu pravé rameno. Líc zdi před žárem chránila $10 \mathrm{~cm}$ tlustá vrstva mazanice. Přibližně $0,10 \mathrm{~m}$ před ní se obě protilehlé stěny kanálu pravoúhle rozšśřily a prostoupily patky klenby. Nedosedaly však až na podlahu kanálu, ale končily přibližně uprostřed, mezi ní a patkou segmentového sklenutí (obr. 10). Usazený jemný popel a dehtem nasycená podlaha kanálu před jeho závěrem naznačují užití bočního komínu při východní stěně místnosti. Jednoznačné určení funkce těchto svislých dráží však zůstává otázkou. Rovněž dva sokly o výšce a šiřce $5 \mathrm{~cm}$ a o délce ca $20 \mathrm{~cm}$ vystupující na podlaze bočního kanálu při jeho severní stěně zůstávají pro nás bez určení funkce.

Odkryté kanály vznikly ve výkopu s výplní vrstev 109 a 111. Stěny zpevnila jílová omazávka (vrstva 107) s kameny na vnějších stranách (obr. 8). Užíváním kanálů došlo k typickému výpalu jílu se zčernalým tvrdým povrchem, za kterým jíl barevně přechází z hnědočervených odstínů přes oranžové až do přírodní žluté barvy výchozího materiálu. Svislé stěny se v pravém úhlu ostře zalamují k rovné hladké podlaze, rovněž zpevněné vypáleným jílem. Horní okraje svislých stěn zakončovaly vodorovné drážky, sloužící pravděpodobně šalování segmentové klenby. Prkna šalování by byla nejspíše využita jako ztracené bednění, spálené žárem při užití otopného zařízení. Současně tak mohlo posloužit i k výpalu vysušených jílových cihel, které kanál sklenuly.

Přikládací otvor prostupující do hlavního průčelí vybouráním zeslabené zdi sonda odkryla pouze částečně. Ukázala oproti podlaze kanálu jen nepatrně zvýšený cihlový práh a naznačila cihlovou klenbu (obr. 11). Přrikládací prostor před jižním průčelím křídla naznačuje několik zdí, které se dochovaly pouze ve fragmentech. Vzhledem k četným výkopům inženýrských sítí

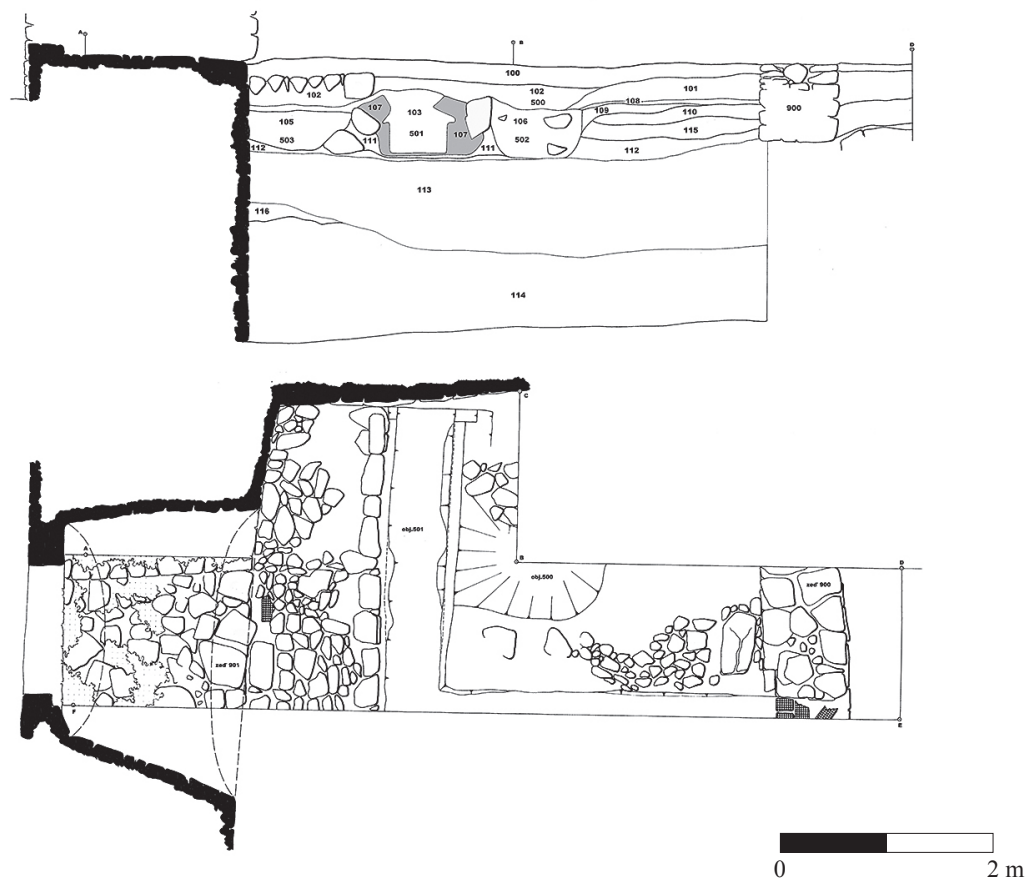

Obr. 8. Sonda 1a/12. Kresba B. Linhartová.

Abb. 8. Sondierschnitt 1a/12. Zeichnung B. Linhartová. 


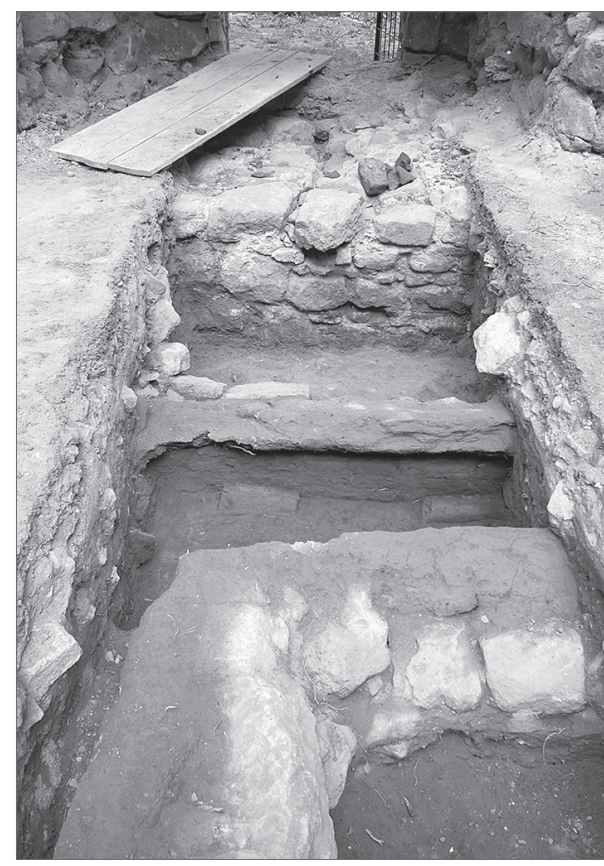

Obr. 9. Sonda 1a/12 před rozšířením. Foto L. Kursová.

Abb. 9. Sondierschnitt 1a/12 vor seiner Vergrößerung. Foto L. Kursová.

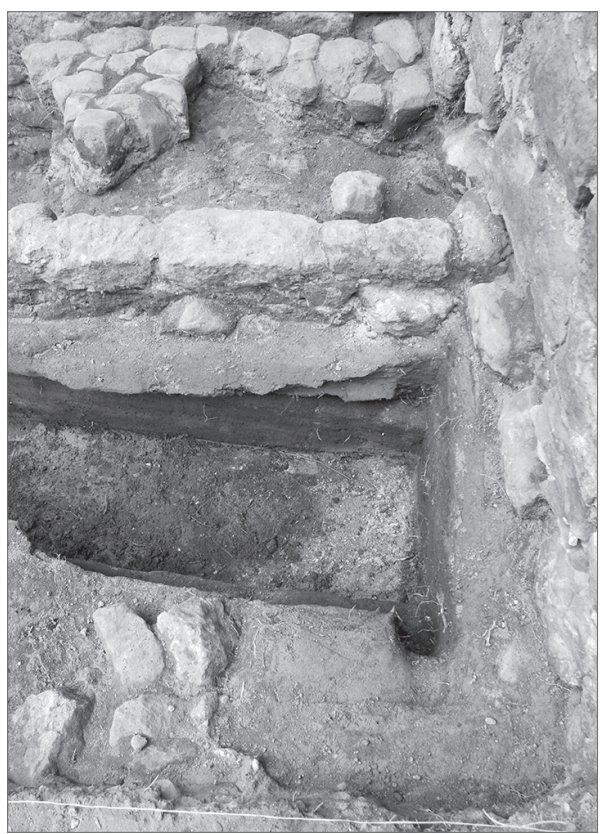

Obr. 10. Kontakt východní strany bočního kanálu s východní obvodovou zdí. Foto L. Kursová.

Abb. 10. Kontakt der Ostseite des Seitenkanals mit östlicher Außenmauer. Foto L. Kursová.

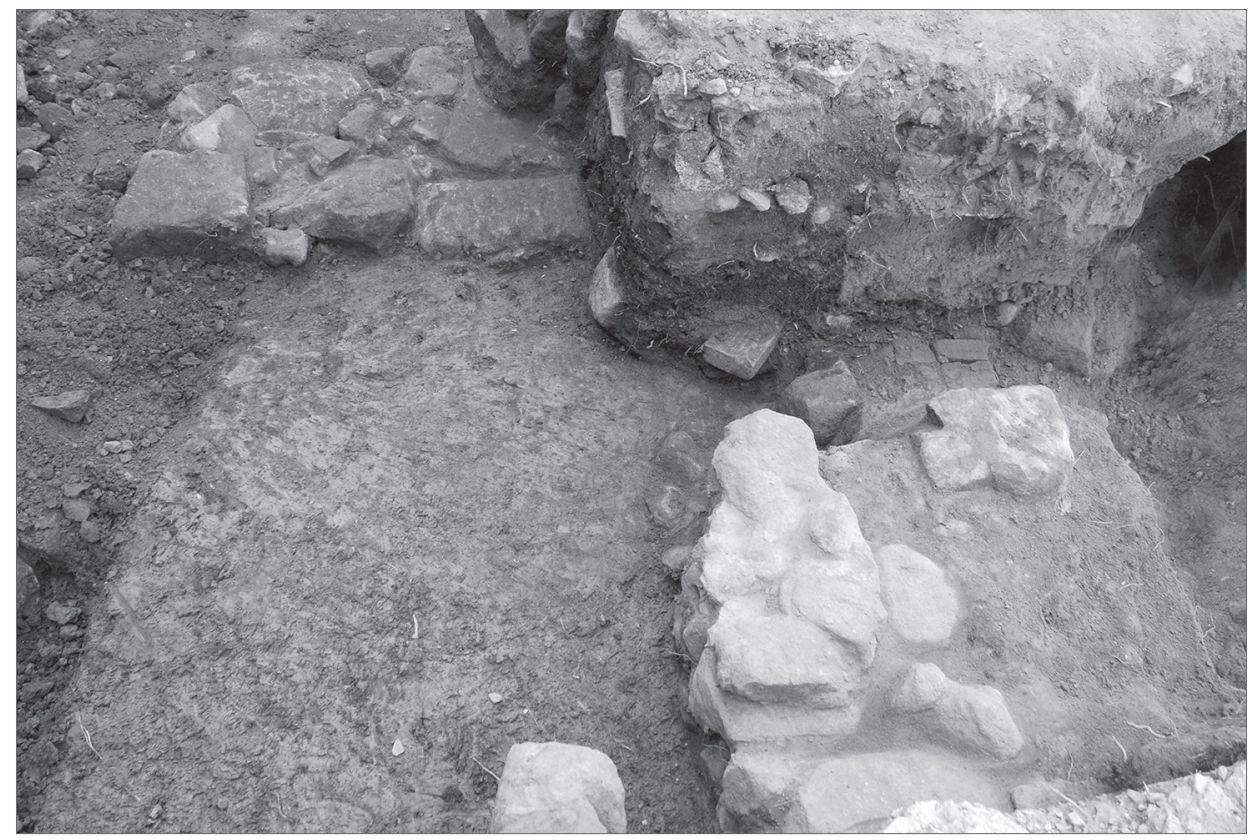

Obr. 11. Přikládací otvor hlavního kanálu otopného zařízení, prostupující východní částí jižní obvodové zdi. Foto L. Kursová.

Abb. 11. Nachfüllöffnung des durch den Ostteil der südlichen Außenmauer gehenden Hauptkanals der Heizanlage. Foto L. Kursová. 


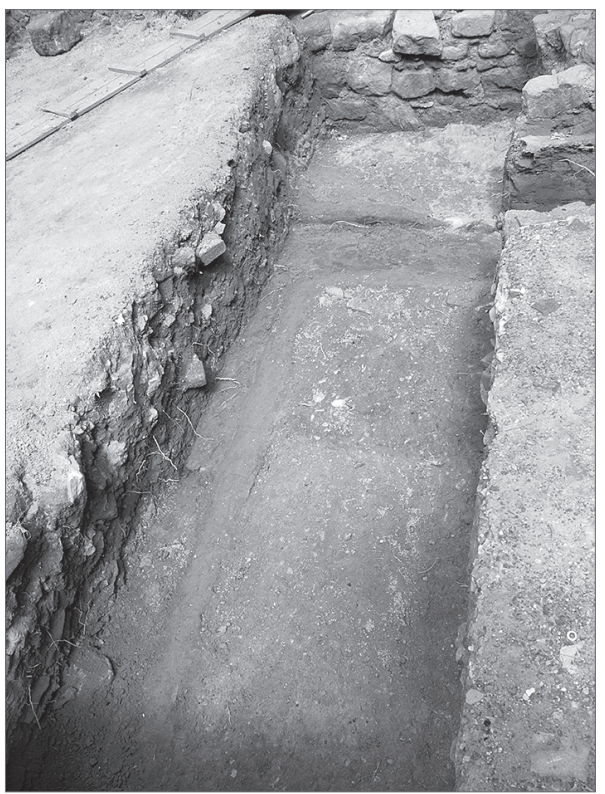

Obr. 12. Východní polovina podlahy hlavního kanálu otopného zařízení. Foto L. Kursová.

Abb. 12. Östliche Fußbodenhälfte des Hauptkanals der Heizanlage. Foto L. Kursová. a rozsahu sondy nebylo možné složitou situaci dořešit a výzkum v těchto místech neposkytl jednoznačné informace.

Stěny a podlaha kanálů byly zahloubeny do výkopu světle hnědé, středně ulehlé vrstvy hlinitého písku (vrstva 111), kterou narušovaly další dvě stratigrafické jednotky (obr. 8). Objekt 502, na rozdíl od objektu 503, nebyl ke kanálům ve stratigrafickém vztahu. Výpln̆ objektu 503 však překryla výplň kanálu (vrstva 103), takže je nepochybné, že objekt 503 zanik1 dřive než otopné zařízení. Vrstva 111 spolu s vrstvou 109 (hlinitá kyprá půda) tvořily výplň zahloubeniny, prostupují vrstvami 110 (okrový písek), 115 (hlinitý, středně ulehlý písek) a 112 (hnědožlutý písek). Souvrství nasedalo na vrstvu kyprého růžovohnědého hlinitého písku (113) s větším množstvím stavební keramiky a pískovcových kamenů. Nepochybně se jednalo o stavební destrukci nasedající na světlý žlutohnědý písek (114) s pískovcovými balvany, fragmenty malty a stavební keramiky. I tuto vrstvu považujeme za destrukci, jejíž uložení mohlo souviset se stavbou obvodové hradby založené na skalním podloží, na kterém leží i vrstva 114 .

Po ukončení funkce otopného zařízení došlo k odstranění klenby kanálů a jejímu vyplnění hnědou středně ulehlou prachovou jílovitou hlínou (103) s pískovcovými kameny, kameny alkalického bazaltu a rozplavenými hrudkami jílu a mazanice. Malý obsah jílu a mazanice (ca $20 \%$ ) naznačuje, že cihlová klenba se do kanálu nezřítila, ale byla odstraněna a kanál vyplnila jiná uloženina. Platí to však pouze o bočním kanálu, nebot' hlavní kanál vyplnila vrstva mazanice, překrytá až v horní části kanálu hnědou středně ulehlou prachovou jílovitou hlínou (103) s pískovcovými kameny a kameny alkalického bazaltu (obr. 12).

Relikty kanálu a jeho výplň zarovnala vrstva šedého středně ulehlého hlinitého písku (102) s drobnými kamínky alkalického bazaltu, pískovce a drobnými fragmenty stavební keramiky. Vrstva pravděpodobně tvořila podlahu, do které byla osazena dlažba z alkalického bazaltu balvanité odlučnosti, lemovaná na severní stěně bočního kanálu pískovcovými kvádry. S ohledem na respektování okraje bočního kanálu okrajem dlažby se zdá, že vydláždění proběhlo současně nebo krátce po zániku otopného zařízení, avšak rozhodně nikoliv v době jeho užívání.

\section{3 Čtvercový objekt v rozšíření sondy $1 b / 12$}

Při průzkumu hradního nádvoří sondou $1 \mathrm{~b} / 12$ se propadla část severního profilu a odhalila dutý prostor. $\mathrm{Z}$ tohoto důvodu výzkum rozšiřil sondu u jejího severního profilu o čtvercový výkop, který svými rozměry ca $1,00 \times 1,00 \mathrm{~m}$ dosahuje až k části východní poloviny jižní obvodové zdi severního kř́ídla hradu, pod jejíž mírně rozšířený základ zkoumaný objekt zabíhá. Čtvercový objekt prostupuje antropogenním souvrstvím o mocnosti $1,42 \mathrm{~m}$, jeho 0,87 m mocným jílovitohlinitým podložím a pokračuje vysekáním 4,13 m do pískovcové skály (obr. 13).

Začištění líce jižní zdi severního křídla odkrylo její mírně rozšířený základ, založený v jílovitohlinitém podloží antropogenních vrstev (obr. 14). Hrubě přisekané pískovcové kvádry zděné na hubenou zvětralou maltu o mocnosti až 0,05 m nepravidelně předstupují před nadzemní 


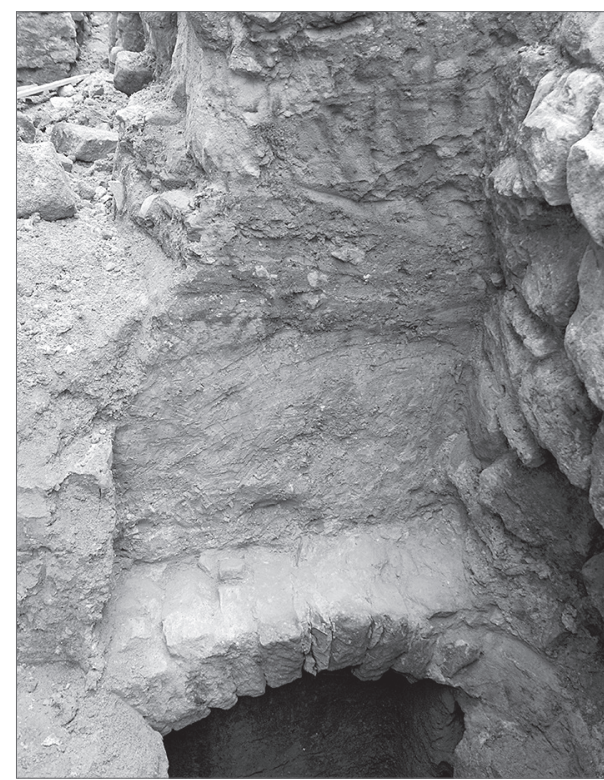

Obr. 13. Západní profil nad čtvercovým objektem v sondě $1 b / 12$ po odstranění zdi nad segmentovým pasem. Foto L. Kursová.

Abb. 13. Westprofil über dem quadratischen Objekt in Sondierschnitt 1b/12 nach Beseitigung der Mauer über dem Segmentstreifen. Foto L. Kursová.

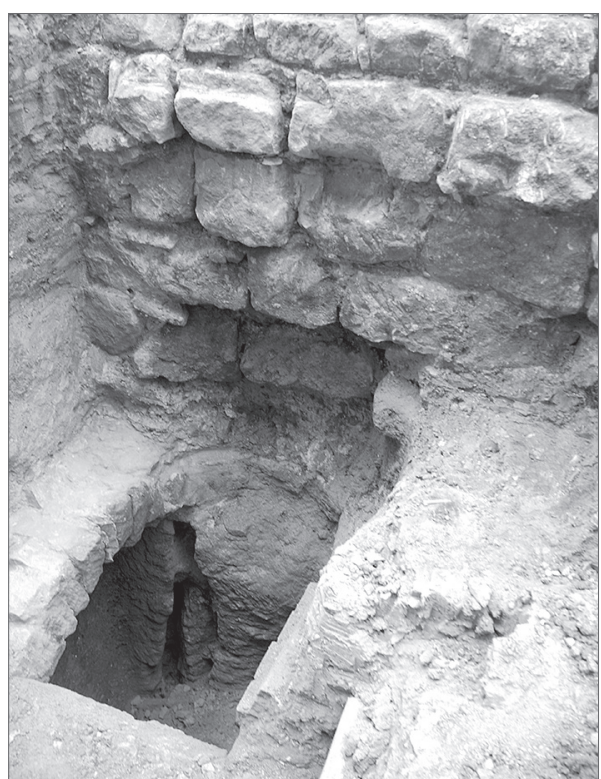

Obr. 14. Základ jižního průčelí severního křídla nad čtvercovým objektem v sondě $1 b / 12$. Foto $L$. Kursová.

Abb. 14. Fundament der Südfassade des Nordflügels über dem quadratischen Objekt in Sondierschnitt 1b/12. Foto L. Kursová.

líc zdi o 0,10-0,20 m nejspíše podle stěny výkopu. Základ současně tvoří severní stěnu objektu v úrovni sypkých antropogenních vrstev. Do rozšířeného líce základu je přes jednu z ložných spár vysekána mělká kapsa (ca $0,20 \times 0,20 \mathrm{~m}$ ), sloužící nejspíše pro horizontálně vynesený trám vznášející se rovnoběžně nad hranou východní stěny objektu. Pod stěnou, druhotně odlámanou asi o $0,20 \mathrm{~m}$, pokračuje jílovitohlinité podloží antropogenních vrstev (ca $0,30 \mathrm{~m}$ ). Dosedá na hranu severní stěny části objektu vysekané do pískovcové skály. Zděný základ, sloužící současně jako severní stěna objektu, dává tušit, že severní křídlo hradního jádra vzniklo až po navýšení terénu o asi 1,00 m mocnou vrstvu stavební destrukce a s vyhloubením objektu nepočítalo. Došlo k němu až později. Při jeho hloubení stratigrafickými jednotkami odkrylo neuspořádané založení základu zdi, se kterým se vyrovnalo odlámáním jeho spodních vrstev.

Horní část západní stěny zpevňovala zed' z hrubě přisekaných pískovcových kvádrů kladených na sucho nebo na hlínu (obr. 15). Ač sama s pečlivě uspřádanou plochou líce, vyrovnávala se při přiložení na spáru k nerovnému líci základu severního křídla. Západní zed' byla založena na segmentovém pasu, který překlenul zhruba západní třetinu objektu.

Na jižní straně můžeme vymezení šachty zdí pouze předpokládat. Nejspíše ji zničil výkop inženýrské sítě. Založena však mohla být i na zříceném cihlovém pasu.

Rovněž zajištění východní strany se nedochovalo. Přibližně pouze polovinu od jižní hrany šachty zajistila cihlová zed' na maltu, dochovaná do výšky jedné čtvrtiny (obr. 16). Nepřekryla tak ani celou mocnost vrstvy jílovitohlinitého podloží. Není vyloučeno, že horní tři čtvrtiny zajištovalo dřevěné obložení, se kterým by souvisel trám, jehož zhlaví bylo zasazeno v kapse severní zdi. Nejspíše později sedimentovala na nerovném profilu vrstev vápenná malta či vápno. O zajištění druhé severní poloviny neposkytl výzkum žádné doklady.

Patky segmentu vynášející západní zděnou stranu šachty se opřely o hrany skalního podloží a přesáhly až do jílovitohlinitého podloží. Segment, vyklenutý z pískovcových kamenů 


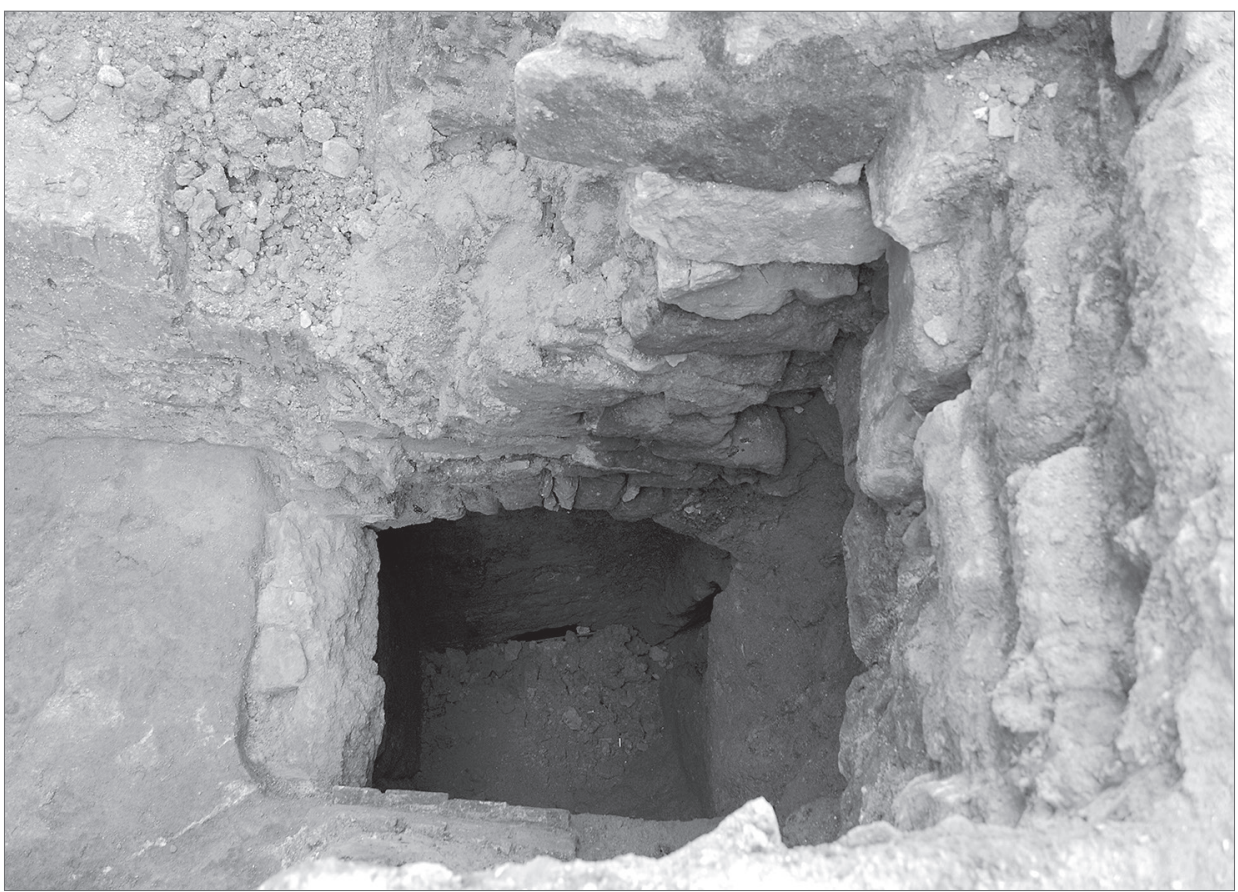

Obr. 15. Západní zed’ nad čtvercovým objektem v sondě $1 \mathrm{~b} / 12$ na segmentovém pasu. Foto L. Kursová.

Abb. 15. Westmauer über dem quadratischen Objekt in Sondierschnitt 1b/12. Foto L. Kursová.

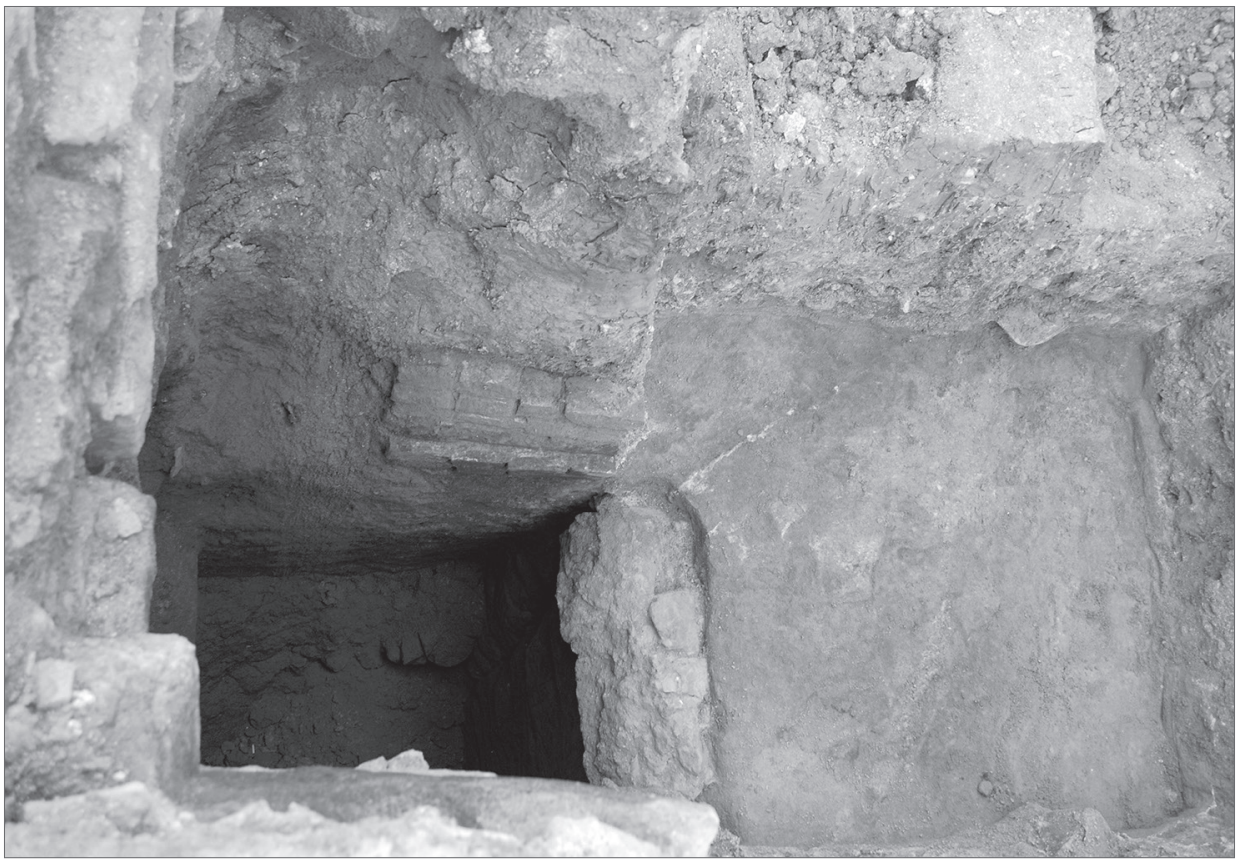

Obr. 16. Východní cihlová zed' nad čtvercovým objektem v sondě 1b/12. Foto L. Kursová.

Abb. 16. Östliche Ziegelsteinmauer über dem quadratischen Objekt in Sondierschnitt 1b/12. Foto L. Kursová. 
proložených znělcovými šíbry, je zalícován se západní zdí. Zdá se však, že k líci přisedal další pas, sklenutý z cihel. Náležela by mu zděná patka na jižní hraně skalního podloží, jejíž opora na protilehlé straně ale není patrná. Vysvětlení nabízí usazení patky v jílovitohlinitém podloží, které se po zániku objektu sesulo. Pravděpodobnější se však jeví sklenutí pouze polovaleného segmentu, vzepřeného o další oblouk vyklenutý příčně. Jeho východní patka dosedla na severní okraj koruny cihlové zdi šachty, kde pro ni zedníci přisekali do šikminy dvojici cihel (obr. 16). Západní patka se opřela do zdi na východní straně šachty. Místo, které by její poloze odpovídalo, zničilo hloubení pro inženýrské sítě.

Spodní část objektu vysekaná ve skalním podloží měří $0,74 \times 0,72 \mathrm{~m}$. Svislé stěny s ostrými kouty prot’aly skalní puklinu (obr. 17). Ploché dno se uklání k západu. V jeho středu je vysekanou nepravidelně oválnou zahloubeninou proražen nevelký otvor do sklepa. Druhý otvor do suterénu prorazil větší otvor při podlaze západní stěnou.

Dutinu překrývala vrstva s dlažbou a jejím nadložím.

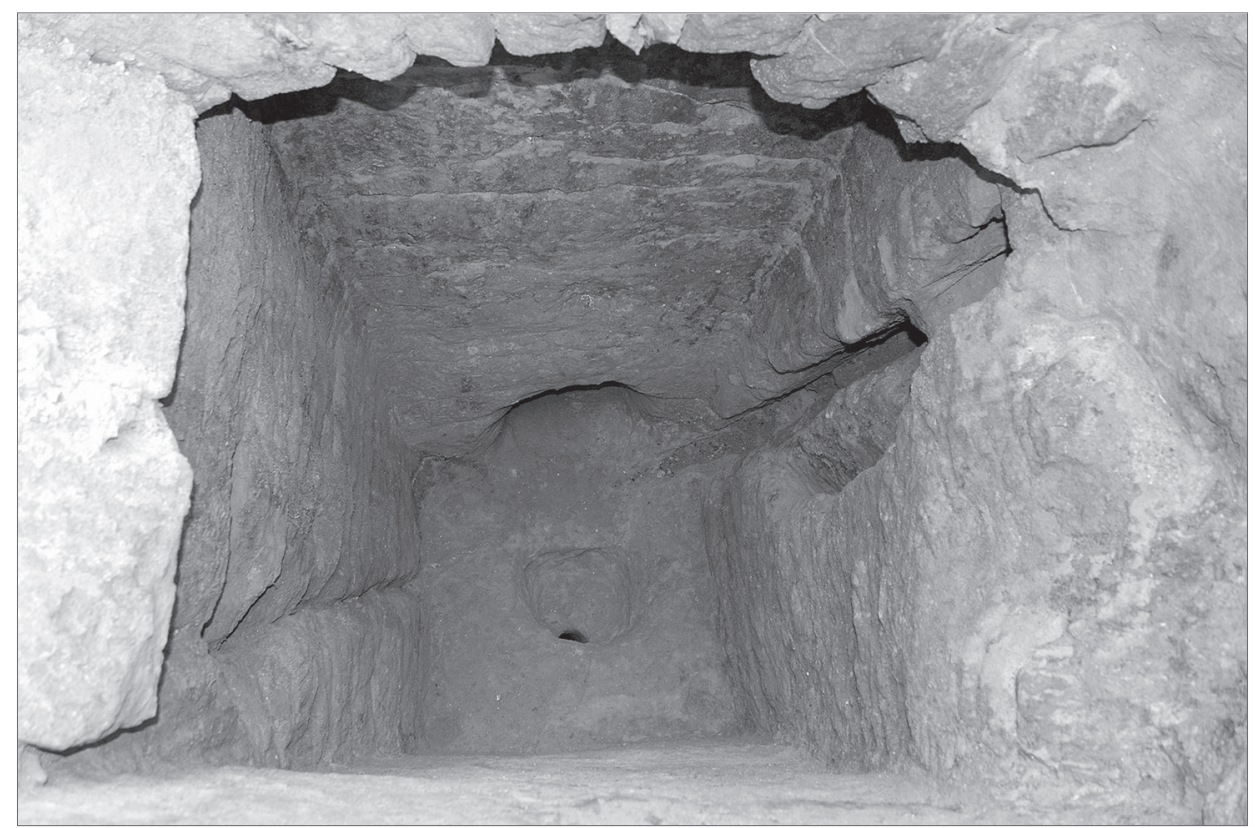

Obr. 17. V pískovci vysekaná část čtvercového objektu a jeho dno. Foto L. Kursová.

Abb. 17. Im Sandstein herausgehauener Teil des quadratischen Objektes und sein Boden. Foto L. Kursová.

\section{Problémy interpretace východní poloviny severního kř́ídla a jeho objektů}

Tři archeologické sondy položené v jádru úštěckého hradu poskytly řadu informací o jeho podobě a vývoji. Vedle odkrytých objektů zachycených graficky, fotograficky i verbální deskripcí nabídly sondy i další informace, mimo jiné dovolující stanovit absolutní datování některých stratigrafických jednotek a jejich pomocí je uplatnit i na jednotky, které absolutní dataci neposkytují. Jedná se především o movité artefakty, zvláště o četné fragmenty keramiky. Jejich vyhodnocení však přesahuje možnosti předkládané práce a bude mu třeba věnovat pozornost na jiném místě. Zde je využito pouze rámcově pro upřesnění relativního datování. 


\subsection{Otopné zař́zenív sondě $1 a / 12$}

Interpretace části hlavního a pravého ramene otopného zařízení jednoznačně dokládá souvislost s topeništěm vyhřívajícím podlahu místnosti. Při hledání analogií narážíme na problém dispozice kanálů, které známe ve tvaru T nebo I. Topný kanál dispozice T odkryl V. Nekuda (1985, 60-63) při výzkumu zaniklé stř̌edověké vesnice Mstěnice (k. ú. Hrotovice, okr. Třebíč) a interpretoval jej jako polyfunkční sušárnu na obilí, ovoce a jiné plodiny. Stejného názoru je i L. Skružný (1980, 229-231), který existenci „sušných jizeb“ klade již do 12. století a jejich užívání ještě do období technické a agrární revoluce, kdy na „stejném principu byly založeny i novověké pazderny a konopice, v nichž se sušil a lámal len a konopi". S řadou dispozičně jednodušších i podobných kanálů se setkal archeologický výzkum předměstí Sezimova Ústí na levobřeží Lužnice (k. ú. Sezimovo Ústí, okr. Tábor). Jejich funkce je spojována se sušárnami hrnčířských výrobků před výpalem, ale rovněž obecně se sušárnou (Richter-Krajíc 2001). Rovněž nejednoznačnou funkci připisuje F. Gabriel $(2003,151)$ dispozičně jednoduchým teplovzdušným kanálům na hradě Helfenburku.

Odkrytá část otopného kanálu úštěckého hradu má nepochybnou dispozici tvaru L s horní stranou obrácenou k jižní obvodové zdi severního křídla, kterou prostupoval přikládací otvor. Nabízí se sice možnost, že se na západní, nezkoumané straně dispozice zrcadlově opakovala a vytvářela na podlaze kanál ve tvaru $T$, tento model však funkci sušárny na ovoce pravděpodobně vylučuje. Podle rozboru stojících sušáren vyhloubených v pískovci, který podrobně a pečlivě vypracoval K. Podroužek (2018, 199-273), musíme předpokládat u nejvyvinutějších typů až čtyři místnosti. Z nich nejdůležitější a pro funkci sušárny ve formální struktuře nezbytná je sušicí komora. $\mathrm{Z}$ řady stop a reliktů, které dokládají sušicí komoru, odkryl ve sledovaném př́ípadě archeologický výzkum pouze dva topné kanály. Další dvě nezbytné činnosti vyžadovaly prostory uváděné K. Podroužkem $(2018,233)$ jako vytápěcí prostor, ze kterého se přikládalo do otopného zařízení sušárny, a manipulační prostor, který sloužil k plnění a vybírání lís. První z nich nepochybně vymezuje přikládací otvor v jižní obvodové zdi severního křídla, kde sonda 1b/12 odkryla značně narušené zbytky zdí, které mohly sloužit pro zpevnění předpecní jámy. Prostor ležel v př́zemí zástavby východní strany dvora.

Polohu manipulačního prostoru neznáme. $\mathrm{V}$ dochovaných sušárnách se dá dovodit ze stop po lešení udávajícím směr zasouvání lís. V našem př́ípadě však stopy po lešení neznáme a jedinými kritérii se tak stává možnost oddělení sušicí komory vhodnou slabou konstrukcí od manipulačního prostoru, jehož plocha musí, pro možnou manipulaci s lísami, nutně přesahovat prostor sušicí komory. První kritérium jednoznačně vyřazuje společný manipulační a vytápěcí prostor, oddělený od sušicí komory tlustou kamennou zdí, nevhodnou k pořízení úzkých, ale dlouhých otvorů pro zasouvání lís. Stěna ve formě rámu musela manipulační prostor oddělit od sušicí komory v místnosti vymezené obvodovými zdmi severního křídla hradu a jeho východní prŕččkou. S ohledem na rozsah hlavního a pravého kanálu zbývá pouze prostor při severní obvodové zdi za koncem hlavního kanálu, nebo prostor vlevo od kanálu levého, který však pouze předpokládáme a rovněž jeho délku pouze odhadujeme podle modelu zrcadlově otočené pravé strany. V takovém př́padě však šiřka sušicí komory vymezí vlevo nevelkou úzkou místnost, zcela nevhodnou k ukládání ovoce na lísy a k jejich vyjímání po usušení. Z tohoto důvodu musíme ustoupit od zrcadlového obrácení pravého kanálu na západní stranu. Rám musel místnost předělit na dvě poloviny, tedy asi ve vzdálenosti $3,50 \mathrm{~m}$, takže topný kanál by měl pouze pravé rameno a k odkrytí chybí pouze západní strana hlavního kanálu. ${ }^{1}$

Jinou funkci východní místnosti severního křídla hradního jádra nabízí její zařazení do výroby piva, kde by plnila funkci hvozdu. Její lísy, jak vyplývá z práce J. T. Suka (1880, 229-250), se z komory nevytahovaly, ale zůstávaly v ní připevněny. Obilí se na lísy „nastíralo“, na nich „obracelo“a nakonec

1 Poslední prostor, který K. Podroužek $(2018,233)$ představuje jako prostor pro odpočinek sušiče, mohl využívat jak prostor manipulační, tak i vytápěcí. Mohl být tedy situován v přizemí zástavby východní strany dvora, nebo ve východní místnosti při sušicí komoře. Další alternativu nabízí poloha sušárny. Její umístění v hradním jádře nevylučuje, že sušič mohl v její blízkosti bydlet a prostor pro odpočinek spojil se svým domovem. 
„sbíralo“ lopatou. Manipulační prostor tedy sloužil pouze k pohybu hvozdy, a nikoliv k manipulaci s lísami. Jeho plocha tedy nebyla limitována rozměry lís a umožnila by zvětšit plochu sušicí komory.

Datování sušárny lze oprrít o dostavbu při východní obvodové hradbě a sklenutí její severní místnosti. Okenní otvor, který provoz sušárny nepodmiňuje, ale naopak ztěžuje, dostatečně řešilo zřízení př́íčky za hlavním kanálem, nebo zazdění okenního otvoru. Podle podloží topných kanálů, které rámcově datuje keramika do druhé poloviny 15 . století, lze zbudování sušárny položit právě do tohoto období.

\section{2 Čtvercový objekt v sondě $1 b / 12$}

Na rozdíl od sušárny, jejíž topné kanály jednoznačně dokládaly otopné zařízení, do pískovcového podloží vysekaný objekt o ploše $0,74 \times 0,72 \mathrm{~m}$ a o minimální hloubce téměř $7 \mathrm{~m}$ od současného povrchu svoji funkci ani nenaznačuje. Podobný objekt o rozměrech 1,60 × 1,60 m a hloubce 3,48 m byl vysekán do pískovcového podloží na lokalitě Klamorna (k. ú. Dneboh, okr. Mladá Boleslav). Nezměřený objekt vysekaný do pískovcového podloží děčínského zámku lze spatřit z nevelkého otvoru ve stropě jednoho ze sklepů západního suterénu. K narušení jeho dna došlo asi při hloubení suterénu, nebo naopak při hloubení objektu, stejně jako tomu asi bylo na úštěckém hradě.

Do určité míry jsou s uvedenými čtvercovými objekty shodné i válcové objekty odkryté na lokalitě městečka v poloze Sekanka, ležící na ostrohu severně od Hradištka u Davle (k. ú. Hradištko pod Medníkem, okr. Praha-západ). Vedoucí rozsáhlého a vzácně zpracovaného výzkumu M. Richter (1982) zánik městečka datuje do roku 1278, který je tedy rovněž datem ante quem pro zánik uvedených objektů (Richter 1982, 50-52), o kterých se autor domnívá, „že by mohlo jit o zásobnicové jámy na obili '“. Proti této hypotéze stojí fakt, že zásobnice na obilí známe od raně středověkého období jako malé, postupně se však zvětšující džbánovité objekty hloubené ve sprašových půdách nebo v pískovcích. Na druhé straně můžeme zjednodušení tvaru objektů ze Sekanky připsat podloží, do kterého byly zahloubeny a které džbánovitý tvar z technických důvodů nepřipouštělo. I přesto se však zdá, že v našem př́ipadě by vyhloubení čtvercového objektu pro ukládání obilí bylo zbytečné, nebot' asi $10 \mathrm{~m}$ od něho vznikl ve vrcholném středověku vysekáním do pískovcového podloží v areálu úštěckého hradu i objekt džbánovitý (Gabriel-Kursová 2018, 206-208).

Důležitou otázkou při určení funkce zůstávají v případě objektu z úštěckého i děčínského hradu otvory ve dnech. Jejich nejpravděpodobnějším vysvětlením je sice narušení při budování suterénu, nelze však vyloučit ani záměrné prolomení, například pro odvětrávání suterénu.

Funkce sledovaného čtvercového objektu zůstává nezodpovězenou otázkou, stejně jako jeho datování. Podle založení západního úseku jižní obvodové zdi severního křídla, která ústí objektu nerespektuje, je třeba jeho vysekání vložit do období až po založení zdi. Místo zahloubení při líci obvodové zdi a komplikace s podkopáním základu však zjevně nebylo náhodné, ale nejspíše souviselo s jeho funkcí. Podivné je i umístění před vstupem do interiéru, který však mohl vzniknout z okenního otvoru nebo zcela nově až později po zániku objektu. K němu v případě nezáměrného narušení dna mohlo dojít až v době hloubení části suterénu, které dno narušilo. Bylo-li narušení dna záměrem, nebo v případě, že nenarušení funkci nepoškodilo, pak jeho zánik náleží době, která již funkci nepotřebovala nebo ji opomněla. V obou případech překvapí, že objekt nebyl zasypán.

\subsection{Základy zdi v sondě 2/82}

Zachované relikty a uvedená starší dokumentace východní poloviny severního křídla jednoznačně dokazují, že stavba severního křídla nebyla jednorázová. Fotografie (obr. 2) zachytila ještě stojící jižní obvodovou zed’ severního křídla nad sondou $2 / 82$. Sondou odkrytý základ zdi, přerušený výkopem inženýrské sítě, byl zjevně provázán se západním (levým) úsekem stojící zdi a směřoval k jihu, na severovýchodní nároží starší části jižního křídla hradu. Naopak východní (pravý) úsek jižní obvodové zdi severního kř́íla hradu odděluje svislá spára. V režném zdivu se po odpadnutí omítek pohledově uplatnil šmorc mladší východní zdi do starší zdi západní. 
Odlišnou dobu výstavby naznačuje i hlubší položení základu sondou odkrytého reliktu a západní zdi na jedné straně a mělčí založení zdi východní na straně druhé. Dalším náznakem odlišnosti zdí je jejich tloušt'ka. Zatímco západní zed' a její zalomení mělo podle plánu tloušt'ku kolem $1,30 \mathrm{~m}$, přiložená východní zed' měřila $1,15 \mathrm{~m}$.

Pro vztah zdí však nemáme jednoznačnou interpretaci. Nevíme totiž, zda odkrytý základ byl pouhým zalomením západní obvodové zdi, nebo zda pokračoval severním směrem k obvodové hradbě jádra hradu a od samého počátku tak dělil západní prostor od východního. Jistý náznak nabízí plán přízemí (SÚRPMO 1970), kde interiér severního křídla dělí přička východním lícem shodná s východní stranou zalomení západní zdi. Její tloušt'ka je sice výrazně menší $(0,60 \mathrm{~m})$, nelze však přehlédnout sokl koryt doplňující její tloušt'ku do 1,30 m. Ke zúžení zdi mohlo dojít při úpravě západní místnosti na chlév doprovázené odsekáním horní části západní strany zdi a položením koryt na takto vzniklý sokl. Prostor, v tomto prrípadě nejspíše zastřešený, tak od samého počátku sloužil jako severní křídlo, kratší ovšem o východní místnost.

Druhá varianta, spojující odkrytý základ zdi s pouhým zalomením zdi západní, by funkci obou nejspíše dovolila interpretovat pouze jako vnitřní dělení nádvoří, tedy jakési druhé předhradí nebo př́íhrádek, podle toho, jak by vyplynulo z komunikačního schématu celého sídla. Z obou variant pak vyplývají další možné modely naznačující celkové rozvržení hradního jádra. Potvrzení některé z nich by však dnes umožnilo pouze prověřní archeologickou sondáží.

\section{Závěr}

Hodnocení tří odkrytých artefaktů úštěckého hradu nabízí několik modelů, které se při současných znalostech úštěckého hradu jeví jako nejlépe možné. Práce pokládá několik otázek, na které by odpověd' mohlo přinést rozšíření archeologického výzkumu. Jiné spočívají v rozšíření studovaného kontextu a další řada úkolů leží v kritice dobových písemných záznamů. Řada z nich závisí „,pouze“ na zpracování pramenné základny, některé umožní až budoucí stavební aktivity.

Vznik tohoto článku byl podpořen projektem OP VVV Doktorandská škola archeologie: nové metody, technologie a výzkum historického dědictví (CZ.02.2.69/0.0/0.0/16_018/0002686), který je spolufinancován z Evropského sociálního fondu a státního rozpočtu České republiky.

\section{Literatura}

GABRIEL, F., 1983: NZ, ulož. v ARÚ AV ČR, č. j. 2323/85.

- 2003: Otopná zařízení na hradě Helfenburku u Úštěku - Heizeinrichtungen auf der Burg Helfenburk bei Úštěk, Svorník 1, 141-152.

- 2014: NZ, ulož. v Regionálním muzeu v Teplicích.

GABRIEL, F.-KURSOVÁ, L., 2018: K nově zjištěným džbánovitým objektům na pískovci - Neue Erkenntnisse überkrugartige Objektein Sandstein, AH 43, 203-211.

GABRIEL, F.-SMETANA, J., 1986: Ke stavební podobě hradu v Úštěku, Litoměřicko XXI-XXII, 77-95.

NEKUDA, V., 1985: Mstěnice 1. Zaniklá středověká ves u Hrotovic. Brno.

PODROUŽEK, K., 2018: Člověk a pískovec. Ústí nad Labem - Praha.

RICHTER, M., 1982: Hradišt'ko u Davle, městečko ostrovského klášera - Hradišt'ko bei Davle, eine Kleinstadt bes Ostrover Klosters. Praha.

RICHTER, M.-KRAJÍC, R., 2001: Sezimovo Ústí - archeologie středověkého poddanského města 2 - Sezimovo Ústí - Archäologie der mittelalerlichen Untertanenstadt 2. Praha - Sezimovo Ústí - Tábor.

SKRUŽNÝ, L., 1980: Několik poznámek k otázce vývoje a funkce pece ve slovanských, středověkých a novověkých objektech i mimo ně - Zur Frage der Enticklung und Funktion des Herdes innerund Außerhalb der slawischen mittelalterlichen und neuzeitlichen Objekte, AH 5, 221-242. 
SUK, J. T., 1880: Nový Poupě katechismus pro sladovnické učenníky a tovaryše. Praha.

SÚRPMO 1970: Plánová dokumentace Úštěk - hrad. Zaměření současného stavu.

\section{Zusammenfassung}

\section{Drei Artefakte von Burg Úštěk und Probleme ihrer Interpretation}

Die hier vorgelegte Arbeit ist nur eine Teilauswertung von drei bei einer archäologischen Grabung in der östlichen Hälfte des Nordflügels des Burgkerns von Burg Úštěk freigelegten Artefakten sowie der mit ihnen verbundenen Interpretationsprobleme. Vom ganzen Nordflügel des Burgkerns ist lediglich die westliche Hälfte erhalten geblieben. Von der östlichen existieren lediglich noch die nördlichen und östlichen Außenmauern des Flügels, die gleichzeitig als Außenmauern der Burg dienen.

Das im Jahr 1970 durch eine vor der Assanierung des Erdgeschossgebäudes durchgeführte qualitativ hochwertige Bauvermessung dokumentierte Interieur wurde von zwei Trennwänden geteilt. Die westliche, aus Ziegelsteinen bestehende Wand teilte eine Räumlichkeit ab, die in ihrer kürzeren Achse vom Tor her zugänglich war, das auch einem kleineren Fuhrwerk die Durchfahrt erlaubte. Von größerer Bedeutung war die zweite Trennwand, welche die westliche Partie abtrennte. Mit ihrer rekonstruierten Stärke von 1,30 m erreicht sie an der Stelle, an welcher sie dispositionsmäßig abknickt, die Stärke des westlichen Teils der Außenmauer. Der östliche Teil der Mauer ist schwächer und wurde auf Fuge angeschlossen.

Im Rahmen der archäologischen Grabung wurde mit dem an der dispositionsmäßigen leichten Abknickung gelegten Sondierschnitt 2/82 ein Fundament freigelegt, das baulich mit der zur nordöstlichen Ecke des zweistöckigen Gebäudes des Südflügels verlaufenden westlichen Außenmauer verbunden war. Der Fundkontext bietet zwei mögliche, die Disposition des Burgkerns und dessen Wegeschema deutlich beeinflussende Modelle an.

Mit Sondierschnitt 1a/12 wurde unter dem Fußboden der östlichen Räumlichkeit des Nordflügels ein Teil des Objektes freigelegt, den wir als unterirdischen Teil einer Heizanlage interpretieren. Einer Analogie nach handelt es sich um eine Trocknungsanlage aus der zweiten Hälfte des 15. Jahrhunderts.

Bei der Untersuchung des Burghofs durch Sondierschnitt 1b/12 ist ein Teil des nördlichen Profils eingefallen, wodurch der Hohlraum eines Objektes mit der quadratischen Disposition von 0,74 x 0,72 m zum Vorschein kam. Das Objekt wurde in einer Gesamttiefe von fast $7 \mathrm{~m}$ von der heutigen Oberfläche aus den Bodenschichten ausgehoben und aus dem Sandsteinuntergrund herausgehauen. Der flache Boden neigt sich in Richtung Westen. In seiner Mitte wurde mit einer herausgehauenen, unregelmäßig ovalen Eintiefung eine kleine Öffnung in den Keller durchbrochen. Eine zweite Öffnung ins Untergeschoss durchbrach am Fußboden der westlichen Wand eine größere Öffnung. Die Funktion des Objektes wissen wir nicht zu interpretieren.

Die Entstehung des vorliegenden Artikels wurde von dem Projekt OP VVV Doktorandenschule der Archäologie: neue Methoden, Technologien und Erforschung des historischen Erbes (CZ.02.2.69/0.0/0.0/16_018/0002686) gefördert, das aus dem Europäischen Sozialfonds und dem Staatshaushalt der Tschechischen Republik mitfinanziert wird.

doc. PhDr. František Gabriel, Ph.D., Katedra archeologie Fakulty filozofické Západočeské univerzity v Plzni, Sedláčkova 15, 30614 Plzeň, Česká republika,pu-uvpd-cl@volny.cz

Toto dílo lze užít v souladu s licenčními podmínkami Creative Commons BY-NC-ND 4.0 International (https://creativecommons.org/licenses/by-nc-nd/4.0/legalcode). Uvedené se nevztahuje na díla či prvky (např. obrazovou či fotografickou dokumentaci), které jsou v díle užity na základě smluvní licence nebo výjimky či omezení př́slušných práv. 
